\title{
AGILITY: A COMPETITIVE WEAPON FOR SOUTH AFRICAN MANUFACTURERS.
}

\author{
Cornelius J. Fourie and Daniël Schoeman
}

\begin{abstract}
Agility enables a manufacturing enterprise to manage change as part of its routine business. By aligning the whole company to a single strategic vision and goal, together with internal and external initiatives, and the application of technology, such an enterprise will be able to deliver on the key competitive priorities of cost, quality, dependability and flexibility.
\end{abstract}

\section{OPSOMMING}

Ratspasbaarheid stel 'n vervaardigingsonderneming in staat om veranderinge te bestuur as deel van roetine sake. So 'n onderneming is as geheel ingestel op 'n enkele strategiese visie en doelwit. Deur mobilisering van interne en eksterne inisiatiewe en gebruikmaking van gepaste tegnologie, kan die onderneming aflewer teen die sleutelprioriteite van koste, kwaliteit, betroubaarheid en aanpasbaarheid.

${ }^{*}$ Cornelius J. Fourie and Daniël Schoeman

Department of Industrial Engineering

University of Stellenbosch

Stellenbosch

South Africa 


\section{WHAT IS AGILITY?}

Agility is defined by Fliedner and Vokurka [1] as the ability to successfully market a broad range of low cost, high quality products and services with short lead times and in varying volumes that provide enhanced value to customers through customisation. Agility challenges the traditional strategic priorities of cost, quality and dependability by enabling a manufacturer to rapidly respond to any change in market demand, whether this is a change in product characteristics, customer orders, or internal company conditions. Agility merges the four distinctive competencies of cost, quality, dependability and flexibility.

When discussing agility, often the question "Isn't agility just another or a new name for flexibility?" is raised. The answer to this question is negative. The traditional dimensions of flexibility includes those that are product or service related, such as volume, product mix and specification flexibility and those that are process related such as machine changeover, scheduling and innovation flexibility. Agility can easily refer to any of these dimensions of flexibility. However, the difference between agility and flexibility is whether or not the change in market demand has been predicted. Flexibility refers to the capability of rapidly changing from one task to another when changing conditions are defined ahead of time. Agility provides the firm with the ability to respond quickly to unanticipated changes in the marketplace. In an agile organisation, change is managed as a matter of routine.

The next question that arises is usually "Is there a difference between agile manufacturing and world class manufacturing?". The answer to this question is definitely yes. Lean production or world class manufacturing is being very good at doing things that can be controlled. As previously stated, agile manufacturing deals with the things that cannot be controlled. Agility enables the organisation to thrive and prosper in an environment of constant and unpredictable change. It is not only to accommodate change, but to relish the opportunities inherent within a turbulent environment.

Agility is also often confused with ISO 9000 , Total Quality Management (TQM) and business process reengineering (BPR). The difference between agility and these reforms is that these reforms are often implemented as "means without ends". Implementing agility often involves implementing ISO 9000, TQM and BPR, but agility roots them in the "ends" of sustained competitiveness.

\section{THE DIMENSIONS OF AGILITY}

There are four key dimensions of agile competition as stated by Goldman et al. [2]. These are :

- Enriching the customer

- Organising to master change and uncertainty

- Leveraging the impact of people and information.

- Co-operating to enhance competitiveness

The first dimension of enriching the customer entails a quick understanding of the unique requirements of each individual customer and rapidly providing it. The second dimension utilises a new organisational structure provided by techniques such as concurrent engineering and crossfunctional teams in order to master change and uncertainty. The third dimension leverages the impact of people, information and technology. This dimension recognises the importance of employees as a company asset and therefore places greater emphasis on the development of this asset through education, training and empowerment. The fourth dimension entails co-operation in

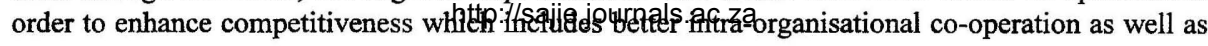


inter-organisational co-operation, such as partnerships with suppliers. It may even be extended to newer, emerging virtual relationships with competing organisations.

\section{AGILITY STRATEGIES}

Numerous strategies can be implemented by an organisation to achieve the above four dimensions of agility. Table 1 [3] presents a view of the top level strategies and underlying capabilities that allow an organisation to be agile. The implementation of agility is however highly context dependent. The appropriate strategy followed will differ for each company, and each company must base its strategy upon an understanding of its customers and markets, products, strengths and weaknesses, competition, and resources. Various combinations of strategies should be pursued by firms with a heightened emphasis on providing greater value to the customer through the ability to offer customised products, services and information.

Table 1 - Agile strategies and capabilities

\begin{tabular}{|c|c|c|c|c|}
\hline $\begin{array}{c}\text { Agile } \\
\text { principles }\end{array}$ & $\begin{array}{l}\text { Enrich the } \\
\text { customer }\end{array}$ & $\begin{array}{c}\text { Master change \& } \\
\text { uncertainty }\end{array}$ & $\begin{array}{l}\text { Leverage } \\
\text { resources }\end{array}$ & $\begin{array}{l}\text { Co-operate to } \\
\text { compete }\end{array}$ \\
\hline $\begin{array}{l}\text { Top level agile } \\
\text { strategies }\end{array}$ & $\begin{array}{l}\text { Solutions are: } \\
\text { - High Value } \\
\text { - Mass } \\
\text { customised; } \\
\text { Niche } \\
\text { - High info } \\
\text { content } \\
\text { - Value priced } \\
\text { - Multiple } \\
\end{array}$ & $\begin{array}{l}\text { - } \text { Change } \\
\text { proficiency } \\
\text { - Reconfigurable } \\
\text { operations } \\
\text { - Rapid response }\end{array}$ & $\begin{array}{l}\text { Entrepreneurial } \\
\text { environment } \\
\text { - Exploit all skills } \\
\text { and knowledge }\end{array}$ & $\begin{array}{l}\text { - Choose to } \\
\text { partner } \\
\text { - Virtual } \\
\text { organisations }\end{array}$ \\
\hline $\begin{array}{l}\text { Principal agile } \\
\text { capabilities }\end{array}$ & $\begin{array}{l}\text { - Continuous } \\
\text { market } \\
\text { analysis } \\
\text { - Intense } \\
\text { customer } \\
\text { focus } \\
\text { - Customer- } \\
\text { driven } \\
\text { quality } \\
\text { - Networks } \\
\end{array}$ & $\begin{array}{l}\text { - Process re- } \\
\text { engineering } \\
\text { - Concurrency } \\
\text { - Modelling \& } \\
\text { simulation } \\
\text { - Change } \\
\text { management } \\
\text { - Networks }\end{array}$ & $\begin{array}{l}\text { - Continuous } \\
\text { communication } \\
\text { - Teaming and } \\
\text { trust } \\
\text { - Open learning } \\
\text { - Value-based } \\
\text { compensation } \\
\text { - Networks }\end{array}$ & $\begin{array}{l}\text { - Partnering } \\
\text { codes } \\
\text { - New legal } \\
\text { style } \\
\text { - IP } \\
\text { management } \\
\text { - Virtual work } \\
\text { skills } \\
\text { - Networks }\end{array}$ \\
\hline
\end{tabular}


These strategies can also be classified as internal and external initiatives, as stated by Fliedner and Vokurka [1]. Examples of internal initiatives include business process reengineering (BPR), adoption of new technology and management planning tools for cycle time and order response time reduction, teamwork, employee empowerment, and employee education and training. Examples of external initiatives, which focus upon supply chain performance improvements, include new forms of partnerships, outsourcing, schedule information sharing, and technology adoption.

\section{IMPLEMENTING AGILITY IN MANUFACTURING}

According to Montgomery and Levine [4], agile manufacturing is achieved through the revitalisation of the production system by implementing agile practises and the alignment of all organisational functions to achieve a shared goal: that of rapidly reacting to market opportunities and to ensure customer satisfaction.

A set of generic enabling practises and technologies have been identified that are critical for achieving agility and should be high on any companies list of imperatives. These imperatives are strongly interdependent and must be addressed simultaneously to realise maximum benefit. These imperatives are listed by the Agility Forum [5] as being:

- Change management

- Workforce flexibility

- Enterprise integration

- Adaptive, responsive information systems

- Rapid product and process realisation

- Extended enterprise collaboration

- Knowledge supply chain

- Innovation management

- Pervasive modelling and simulation

- Next generation manufacturing processes and equipment

In becoming agile manufacturers, organisations have transformed over time. This transformational process is depicted in Table 2. From this table it can be seen that manufacturers that have attained the status of agile manufactures, have gone through four major steps in their transformation. At first glance it seems that a manufacturing enterprise has to go through al four painful steps. This however is not true.

It is here that the opportunity for South African manufacturing enterprises lie. Agile manufacturing is built on a foundation of some, but not all, of the practices common to lean manufacturing, [4]. For example, while both lean and agile manufacturing emphasise small batch sizes, agile manufacturing takes the additional steps of reducing product development time and allowing for considerable customisation of product features. 
Table 2 - The Four Steps to Agile Manufacturing

\begin{tabular}{|c|c|c|c|}
\hline $\begin{array}{c}\text { Traditional } \\
\text { Manufacturing }\end{array}$ & Gaining Control & $\begin{array}{c}\text { World Class } \\
\text { Manufacturing }\end{array}$ & $\begin{array}{c}\text { Agile } \\
\text { Manufacturing }\end{array}$ \\
\hline Complex systems & ERP or MRP II & $\begin{array}{l}\text { Lean } \\
\text { manufacturing }\end{array}$ & $\begin{array}{l}\text { Enriching the } \\
\text { customer }\end{array}$ \\
\hline Departmentalism & $\begin{array}{l}\text { Better customer } \\
\text { service }\end{array}$ & JIT & $\begin{array}{l}\text { Competitiveness } \\
\text { through co- } \\
\text { operation }\end{array}$ \\
\hline EOQ & $\begin{array}{l}\text { Reduced inventory } \\
(10-25 \%)\end{array}$ & $\begin{array}{l}\text { Total Quality } \\
\text { Management. }\end{array}$ & $\begin{array}{l}\text { Organising for } \\
\text { change \& } \\
\text { uncertainty }\end{array}$ \\
\hline $\begin{array}{l}\text { No employee } \\
\text { involved }\end{array}$ & $\begin{array}{l}\text { Lower production } \\
\text { costs }\end{array}$ & Much less costly & $\begin{array}{l}\text { People and } \\
\text { information }\end{array}$ \\
\hline Financial secrecy & Greater flexibility & More responsive & $\begin{array}{l}\text { High customer } \\
\text { flexibility }\end{array}$ \\
\hline High inventory & Better control & $\begin{array}{l}\text { Long term } \\
\text { profitability }\end{array}$ & $\begin{array}{l}\text { Integrated } \\
\text { flexibility }\end{array}$ \\
\hline Inspection & Planned operations & LT improvement & Technology \\
\hline Lack of strategy & $\begin{array}{l}\text { Better } \\
\text { communication }\end{array}$ & $\begin{array}{l}\text { Productivity } \\
\text { Improvement }\end{array}$ & $\begin{array}{l}\text { Highly educated \& } \\
\text { trained work force }\end{array}$ \\
\hline Late delivery & & Time to market & $\begin{array}{l}\text { Flexible } \\
\text { management } \\
\text { structures }\end{array}$ \\
\hline Long cycle times & & Zero defects & $\begin{array}{l}\text { Virtual } \\
\text { corporations }\end{array}$ \\
\hline Politics & & Inventory turns & \\
\hline \multicolumn{4}{|l|}{ Record inaccuracy } \\
\hline \multicolumn{4}{|l|}{ Shortages/Expedite } \\
\hline Month-end push & & & \\
\hline
\end{tabular}

A manufacturer thus does not have to achieve world class manufacturing status before it can become an agile manufacturer. Learning from the lessons of other manufacturers in the USA and UK, it is now possible for South African manufacturers to achieve agile manufacturing in a shorter time, due to the shorter learning curve, and also by avoiding the costly mistakes known through the experiences of USA and UK manufacturers.

Companies currently implementing world class manufacturing that wishes to achieve agility need not scrap all previous efforts. From Table 2 it can be seen that agile manufacturing can build on world class manufacturing. Because of the common foundations of agile and world class manufacturing or lean production, the old, yet effective, requirements for implementing world class manufacturing can generally be redirected, rather than scrapped.

The road to agility in South African manufacturing enterprises will not be in leaps and bounds, but it will rather be a painful step-by-step process. Nevertheless, it is crucial for the South African manufacturing industry to start on that journey and to be guided from traditional manufacturing towards the ultimate goal - agile manufacturing. 


\section{A COMPETITIVE WEAPON}

Agile manufacturing is a recent manufacturing process innovation that represents the demise of the century-long tradition of manufacturing driven by scale. It aspires to total flexibility without sacrificing quality or incurring added costs. Agility is about being more competitive - creating the products and services that customers in a rapidly changing, fragmented, global marketplace will buy.

Competitiveness and success cannot be claimed as rights. They are earned through continually matching products and services to what the customer will buy. They are earned through continually responding to changes, in markets, technology, social pressures and legislation. Successful enterprises evolve - not through random mutation - but through purposeful strategies to respond to change.

The only confident prediction that can be made about change is that it will accelerate. That is why agility is not about responding to changes, but having the capabilities and processes to respond to unpredictable change. Agility is about establishing the processes that allow an enterprise to master change so as to be able to offer the products that customers will value.

Agility International [3] predicts that agile companies will profit from:

- New markets for niche, customised products and services

- Long-term relationships with customers

- Faster concept to cash time

- Turning change into market opportunity

- Greater bottom-line impact of people, information and technology

- Multiple win/win partnerships

Reported benefits from implementing agility also include: lower costs, higher quality levels, shorter lead times, and greater customer satisfaction. If these benefits are possible with agility, indeed, it would seem that agility is a competitive weapon for South African manufacturers in the $21^{\text {st }}$ century.

\section{REFERENCES}

[1] Fliedner, Gene and Vokurka, Robert (1997), Agility: The Next Competitive Weapon, APICS The Performance Advantage, January 1997, pp. 56-59.

[2] Goldman, Steven L., Nagel, Roger N., Preiss, Kenneth (1995), Agile Competitors and Virtual Organizations, Strategies for Enriching the Customer, VanNostrand Reinhold.

[3] Agility International 1996, 1997. Published at http://www.aglity.co.uk/ai

[4] Montgomery, Joseph C. and Levine, Lawrence O., Editors (1996), The Transition to Agile Manufacturing, Staying Flexible for Competitive Advantage, ASQC Quality Press, USA.

[5] Agility Forum. Published at http://www.aglityforum.org 